\title{
Challenges for the closure and natural rehabilitation of bauxite residue disposal sites
}

\author{
O Torgersrud Norwegian Geotechnical Institute, Norway \\ GD Breedveld University of Oslo, and Norwegian Geotechnical Institute, Norway \\ G Okkenhaug University of Life Sciences, and Norwegian Geotechnical Institute, Norway \\ B Malme Norsk Hydro, Norway \\ P Cataldi Norsk Hydro, Brazil
}

\begin{abstract}
In the Bayer process, bauxite ore is digested with $\mathrm{NaOH}$ at high temperature and pressure, which results in the production of alumina and the recrystallisation of various residual minerals ending up in a bauxite residue. The main minerals in this residue, which is commonly referred to as 'red mud', are iron and aluminium oxides (goethite, hematite, gibbsite and boehmite), $\mathrm{Na}$ - and Ca-aluminosilicate phases (e.g. sodalite and cancrinite) and titanium oxide. The main challenges facing the natural rehabilitation (direct revegetation) of bauxite residues are related to inherent physicochemical properties of the bauxite residue, in particular alkalinity, salinity, sodicity and low hydraulic conductivity.

Physical restrictions to growth of vegetation in bauxite residue material include low hydraulic conductivity (low transport of water), poor drainage (water logging) and restricted root growth. Additionally, in dry periods, capillary rise of water and dissolved salts can occur, salts may accumulate at the cap surface, and drying cracks will occur.

Pilot studies have been initiated to compare different closure solutions that take into consideration the physical, chemical and biological limitations of bauxite residues. Methods include the use of different liners, geomembranes, drainage systems and topsoil covers. Gypsum amendment and the addition of organic matter are studied as potential natural rehabilitation methods that can limit the use of pristine soil in the construction of the top cover.

The study is part of the Norwegian Geotechnical Institute's research program on sustainable mine tailings, which comprises studies on material properties, modelling and prediction of physical and chemical stability, remote sensing for long-term monitoring and risk-informed decision-making.
\end{abstract}

Keywords: bauxite residue, disposal, closure, capping

\section{$1 \quad$ Introduction}

Bauxite ore is the primary resource for the production of aluminium. In the Bayer process, bauxite ore is digested with $\mathrm{NaOH}$ at high temperature and pressure, which results in the production of alumina and recrystallisation of various residual minerals, ending up in a bauxite residue. The main minerals in this residue, which is commonly referred to as 'red mud', are iron and aluminium oxides (goethite, hematite, gibbsite, boehmite), $\mathrm{Na}$ - and Ca-aluminosilicate phases (e.g. sodalite, cancrinite) and titanium oxide (Figure 1). Alumina is subsequently used to produce aluminium through smelting, using the Hall-Héroult electrolytic process. For every ton of alumina produced, an equal amount of residue is produced that has to be stored in bauxite residue disposal areas. Residues are inherently characterised by particularly high alkalinity, salinity and sodicity and low hydraulic conductivity. This makes closure and restoration of these sites challenging. 


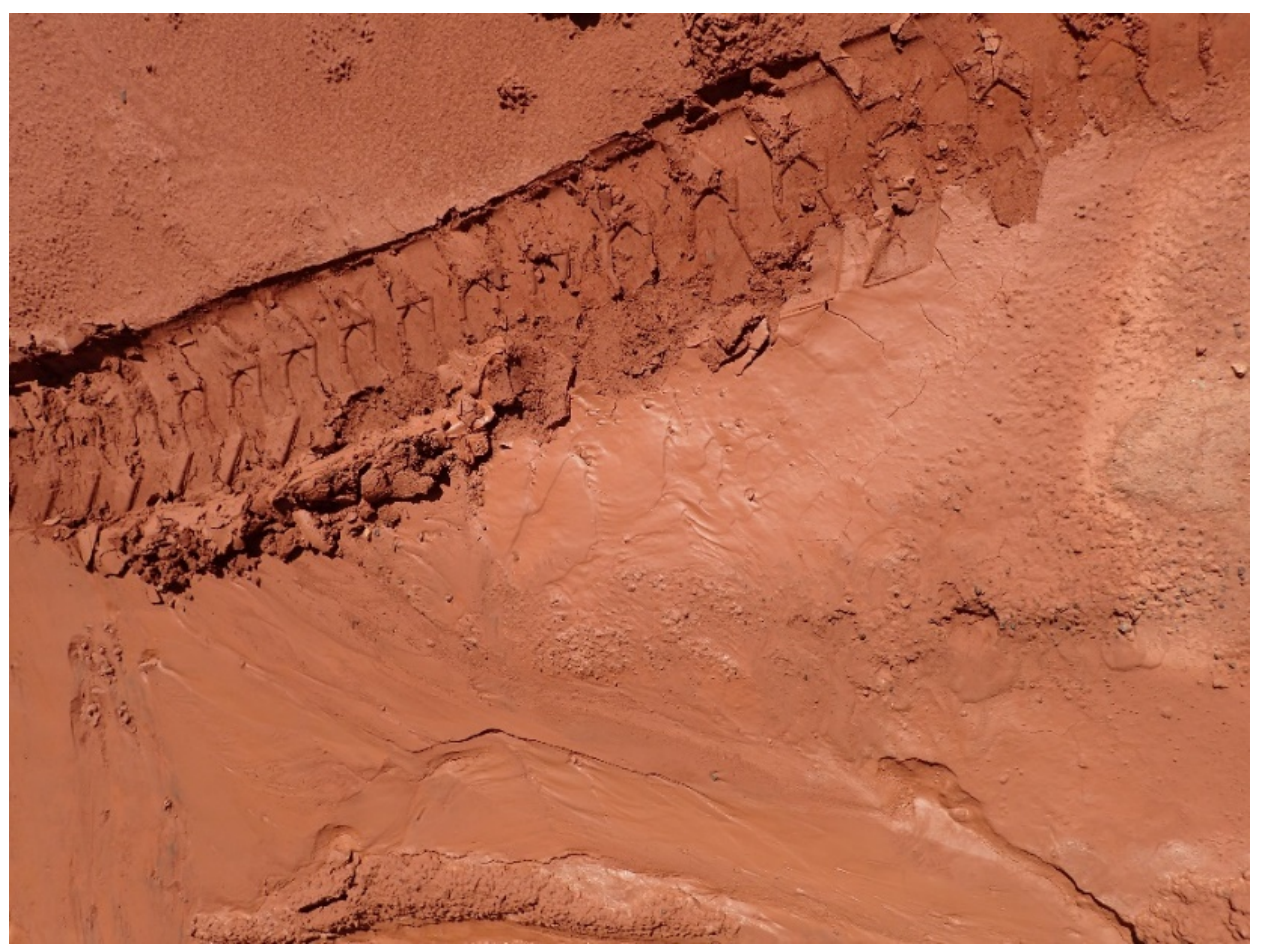

Figure 1 Bauxite residues have a fine texture and a distinct red colour, resulting in the popular name 'red mud'

Physical restrictions to growth of vegetation in bauxite residue material include low hydraulic conductivity (low transport of water), poor drainage (water logging) and restricted root growth. Additionally, in dry periods, capillary rise of water and dissolved salts can occur, salts may accumulate at the cap surface, and drying cracks will occur.

\section{Rehabilitation options}

The main drivers for the closure and rehabilitation of a bauxite residue disposal area are to:

- Eliminate contaminant runoff.

- Control fugitive dust.

- Improve visual impact.

- Reintegrate with adjacent vegetated area.

Several options for a potential top cover that will fulfil these objectives and allow revegetation of bauxite residue disposal areas are evaluated (Table 1 ).

The first three options involve the construction of a soil cap, which requires the use of extensive amounts of external resources such as sand, geotextiles and topsoil. Recent research on the rehabilitation of bauxite residue storage facilities has shown that the use of natural rehabilitation (in situ remediation) is a viable alternative to soil capping and enables the transformation of bauxite residue into a soil capable of supporting a self-sustaining ecosystem. Furthermore, the in situ remediation of bauxite residue is shown to be a cost-effective management strategy, avoiding substantial demand for materials from external sources (e.g. virgin soil) as well as transport and landscaping costs associated with soil capping (Bray et al. 2018; Di Carlo \& Courtney 2018; Santini \& Fey 2018). 
Table 1 Rehabilitation alternatives using cover systems for bauxite residue disposal areas

\begin{tabular}{lll}
\hline Cover system & Advantages & Disadvantages \\
\hline $\begin{array}{l}\text { Under drained: } \\
\text { Sand layer, local soil, topsoil }\end{array}$ & $\begin{array}{l}\text { Reduction of runoff water } \\
\text { treatment }\end{array}$ & $\begin{array}{l}\text { Some treatment necessary in a } \\
\text { lifetime perspective }\end{array}$ \\
$\begin{array}{l}\text { Liner: } \\
\text { Geocomposite, local soil, topsoil }\end{array}$ & $\begin{array}{l}\text { Complete collection, no } \\
\text { runoff water treatment }\end{array}$ & $\begin{array}{l}\text { Saturated conditions of bauxite } \\
\text { residue }\end{array}$ \\
$\begin{array}{l}\text { Simple topsoil: } \\
\text { Topsoil directly on bauxite residue }\end{array}$ & $\begin{array}{l}\text { Little resource use, simple } \\
\text { construction }\end{array}$ & $\begin{array}{l}\text { Runoff water treatment necessary } \\
\text { on short and mid-term basis }\end{array}$ \\
$\begin{array}{l}\text { Natural rehabilitation: } \\
\text { Amendment of bauxite residue }\end{array}$ & $\begin{array}{l}\text { Little resource use, soil } \\
\text { development over the } \\
\text { long-term }\end{array}$ & $\begin{array}{l}\text { Runoff water treatment necessary } \\
\text { on short and mid-term basis }\end{array}$ \\
\hline
\end{tabular}

To evaluate the most adequate rehabilitation alternative, six experimental areas ( $100 \mathrm{~m} \times 60 \mathrm{~m}$ each) have been constructed to compare the various options and obtain critical design criteria (Figure 2). Areas 1-4 are designed to test various combinations, including liner, drainage system and topsoil cover. Areas 5 and 6 can be used for 'natural rehabilitation', using different amendments. Schematic cap design is shown in Figure 3.

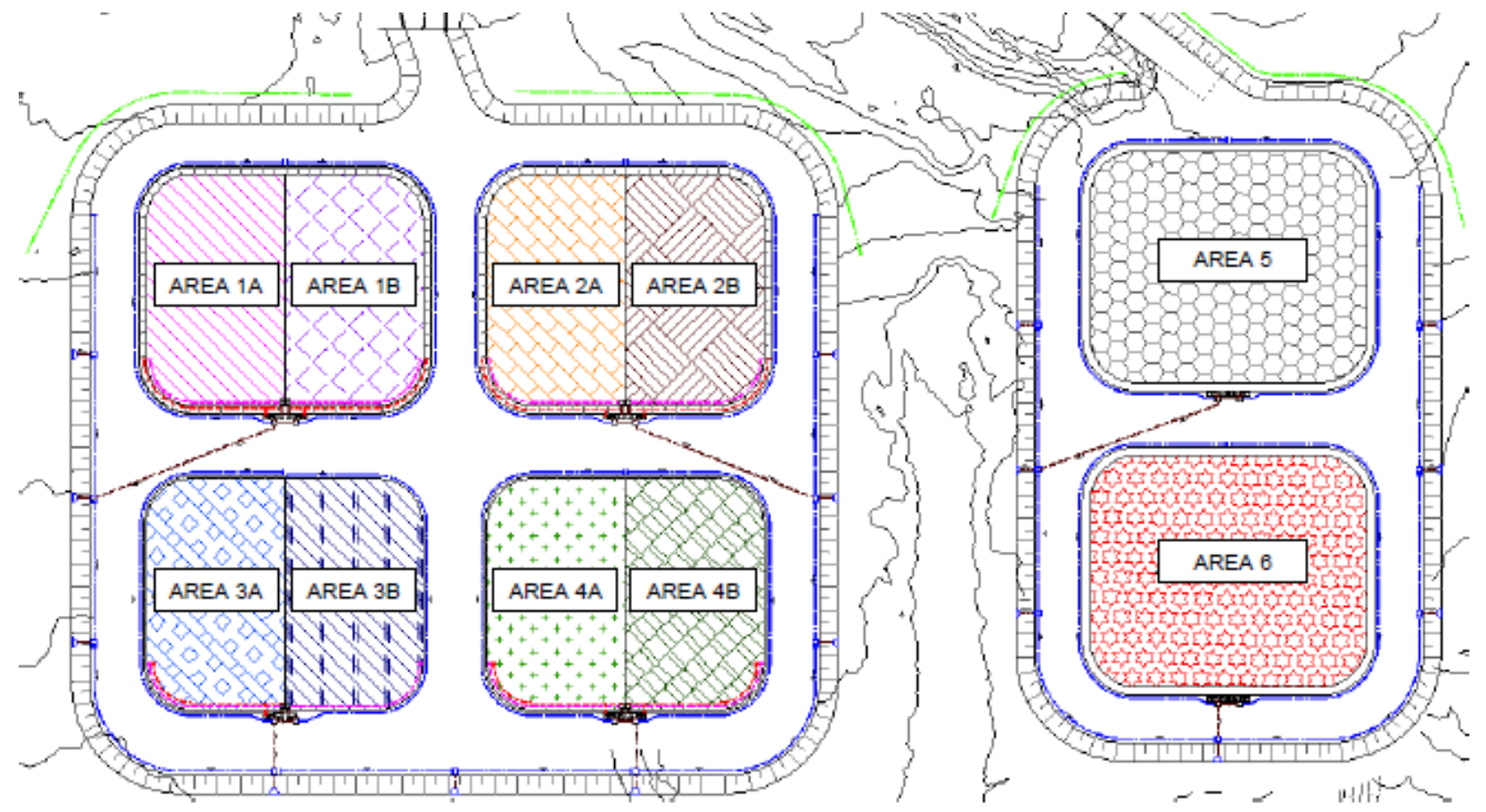

Figure 2 Pilot test sites constructed to compare the various closure solutions: (1) under drained; (2) liner; (3) gypsum and topsoil; (4) simple topsoil; (5\&6) natural rehabilitation

An extensive monitoring program is being initiated to document the performance of the different rehabilitation solutions, involving geotechnical, geochemical and biological parameters as well as continuous logging of leachate water quality. 

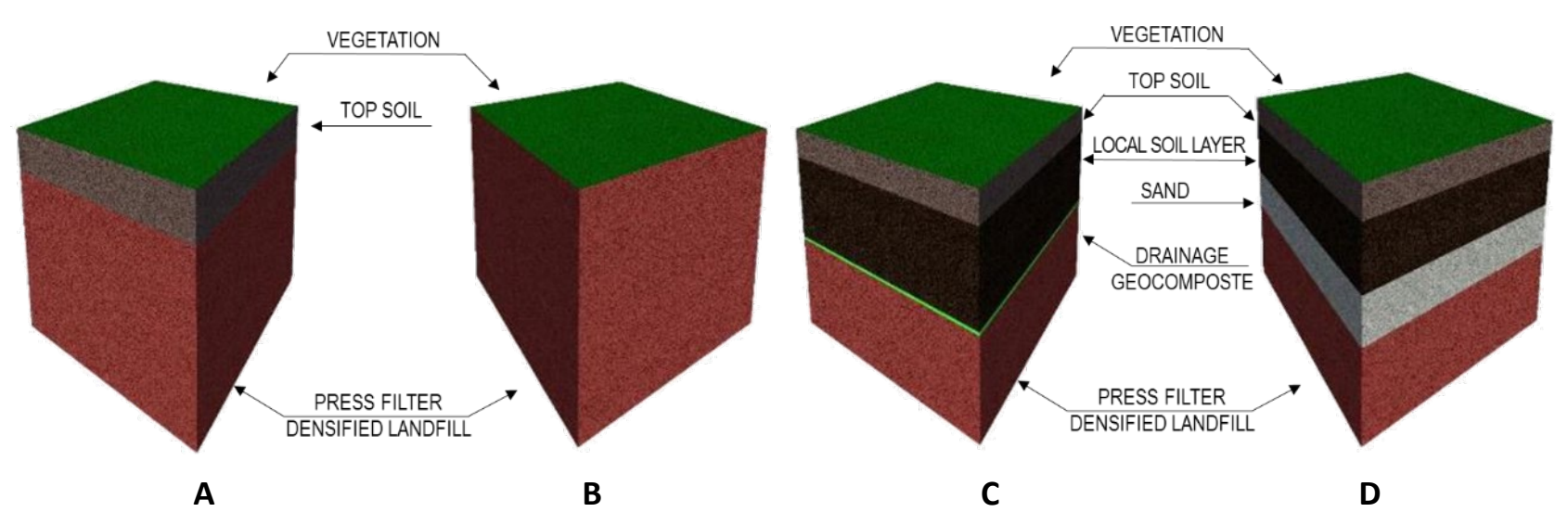

Figure 3 Schematic cap design (A) with topsoil $(30 \mathrm{~cm})$; (B) directly on bauxite residues; (C) with drainage layer of geocomposite, local soil $(60 \mathrm{~cm})$ and topsoil $(20 \mathrm{~cm}) ;(D)$ with drainage layer of sand $(30 \mathrm{~cm})$, local soil $(40 \mathrm{~cm})$ and topsoil $(20 \mathrm{~cm})$

\section{$3 \quad$ Natural rehabilitation}

In the literature, several options are described to decrease alkalinity and salinity/sodicity and improve physical properties in order to improve soil function and possible revegetation. In the case of bauxite residue, in situ remediation means selecting amendments that will aid in lowering $\mathrm{pH}$ values from above 11 and reducing electrical conductivity (EC) from values above $4 \mathrm{mS} / \mathrm{cm}$. Simultaneously, it is desirable to increase cation exchange capacity (and decrease the exchangeable sodium percentage) and stimulate the accumulation of plant and microbial nutrients, such as organic $\mathrm{C}, \mathrm{NH}_{4}{ }^{+}, \mathrm{NO}_{3}{ }^{-}, \mathrm{PO}_{4}{ }^{3-}$, and $\mathrm{K}^{+}$in the residues. These options are currently being tested in laboratory scale before implementation at the pilot test site.

\subsection{Gypsum amendment}

Surface amendment with calcium sulphate (gypsum $\mathrm{CaSO}_{4} \cdot 2 \mathrm{H}_{2} \mathrm{O}$, anhydrite $\mathrm{CaSO}_{4}$ ) is a common method used in connection with bauxite residue remediation (Di Carlo \& Courtney 2018; Jones \& Haynes 2011). Adding gypsum will decrease exchangeable sodium concentration $\left(\mathrm{Ca}^{2+}\right.$ ions exchange against $\left.\mathrm{Na}+\right)$, reducing sodicity of the material. $\mathrm{Na}^{+}$along with added $\mathrm{SO}_{4}{ }^{2-}$ will leach down the profile with the percolating drainage water. Additionally, calcium ions will precipitate with carbonate $\left(\mathrm{CO}_{3}{ }^{2-}\right)$ in soil water to calcite $\left(\mathrm{CaCO}_{3}\right)$ and, in this way, reduce alkalinity and $\mathrm{pH}$. This in turn will reduce Al solubility.

Furthermore, gypsum can promote flocculation of clay particles and the formation of soil aggregates, as well as increase hydraulic conductivity. This is a result of calcium ions displacing the sodium ions on clay particles, which results in a closer packing and better aggregation of the clay particles.

Typically, rates of gypsum application have been in the range of $7 \%-15 \% \mathrm{w} / \mathrm{w}$ ( $35-70$ tons/ha), and these have been shown to result in a large increase in the growth of a range of plant species growing in the residue. Bray et al. (2018) investigated the long-term effects of a surface treatment to bauxite residue. The treatments consisted of (i) process sand from the bauxite processing (10\%), gypsum (3\%) and spent mushroom compost ( $80 \mathrm{t} / \mathrm{ha}$ ) seeded with grassland mix (fully treated), (ii) process sand and spent mushroom compost seeded with grassland mix and (iii) untreated bauxite residue.

Their results showed a substantial decrease in $\mathrm{pH}$ and extractable $\mathrm{Na}$ concentrations in the treated and partially treated bauxite residues, down to a depth of $50 \mathrm{~cm}$, whereas extractable Ca increased in the upper layers in the treated residues.

\subsection{Organic amendment}

Addition of organic matter to bauxite residues will have several positive effects on the plant growth ability. This will include addition of organic carbon as a soil enhancer and supply of plant nutrients (e.g. N, P, S) 
through mineralisation, increased cation exchange capacity through functional groups on humic substances, chelation and formation of stable complexes with metal cations (e.g. $\mathrm{Cu}, \mathrm{Zn}, \mathrm{Mn}, \mathrm{Al}$ ), water retention, and formation and stabilisation of soil structure (Stevenson 1994). Additionally, organic matter is an energy source for soil organisms, including bacteria, fungi, earthworms and other soil fauna.

Introduction and incorporation of organic wastes and amendments into the surface layers of residue will be the most practicable way of increasing microbial activity. This, in turn, will promote the formation of a functioning below-ground ecosystem containing microflora and fauna (e.g. bacteria, fungi, protozoa and nematodes), mesofauna (e.g. collembola, cicari) and macrofauna (e.g. earthworms and termites). These organisms interact in carrying out many soil functions, including the flow of energy and nutrients through the soil system (Jones \& Haynes 2011).

Fermentation of organic matter will contribute to an acidifying effect by generating organic acids and $\mathrm{CO}_{2}$. This may lead to neutralisation of bauxite residue alkalinity. Addition of organic wastes will also increase the water holding capacity and increase the soil structure by creating more-stable aggregates, which, in turn, stabilise channels and pores, allowing drainage and aeration.

\subsection{Residue sand}

Residue sand is a fraction separated from the bauxite material before milling or digesting (Bayer process). The residue sand is a much coarser fraction $(>100 \mu \mathrm{m})$ compared with the bauxite residue mud. To improve the physical properties of the bauxite residue, one strategy is to blend residue sand with the top layer. The sand fraction could increase the hydraulic conductivity, thus improving drainage and leaching. Its lower buffering capacity aids the positive effect of gypsum neutralisation. The increased porosity also promotes root growth. Mixture ratios given in literature indicate a dose of $10-25 \%$ sand in the top $30 \mathrm{~cm}$ of the residue mud surface (Jones \& Haynes 2011).

Residue sand may also be used as a capillary break layer between compacted residue and residue amended for revegetation in order to avoid the capillary rise of water and dissolved salts to the soil surface in dry periods.

\subsection{Fly ash}

Fly ash is a residue from coal-powered boilers. In order to reduce $\mathrm{SO}_{2}$ emission levels, coal-powered boilers are fed with limestone or dolomite, which is calcined to lime and converted to calcium sulphate. This material leaves the boiler along with ash. X-ray fluorescence analysis of the fly ash shows mainly $\mathrm{Si}, \mathrm{Ca}$ and Al along with and smaller amounts of sulphur, iron, sodium and magnesium.

Adding fly ash to the bauxite residue may have a positive effect due to the content of $\mathrm{CaSO}_{4}$ (ion exchange with $\mathrm{Na}$ ). However, the possible high content of lime $(\mathrm{CaO})$ in the ash will increase the alkalinity and thus counteract possible measures to reduce the $\mathrm{pH}$ of the material. Adding more lime or calcite to bauxite residue is considered ineffective in alkaline soil/residues.

\subsection{Carbonation}

Alkaline materials will capture $\mathrm{CO}_{2}$ from the atmosphere, which in turn will react with $\mathrm{OH}^{-}$in the porewater and produce $\mathrm{HCO}_{3}{ }^{-}$and $\mathrm{CO}_{3}{ }^{2-}$. This process is called carbonation: an acidifying reaction reducing $\mathrm{pH}$ and alkalinity.

Carbonisation of bauxite residue is carried out on a large scale on an industrial basis at the Kwinana refinery, Australia, where concentrated $\mathrm{CO}_{2}$ (from an ammonia plant) is mixed in the residue slurry, which can result in a pH reduction to 9 (Power et al. 2009).

Natural atmospheric carbonation of bauxite residues by atmospheric $\mathrm{CO}_{2}$ is also shown to be effective in reducing $\mathrm{pH}$ and alkalinity. McMahon (2017) used a variety of equipment in repeating processes to break the bauxite residue into small lumps in order to allow for increased exposure to $\mathrm{CO}_{2}$ in the air 
(e.g. mud-ridding equipment, ploughing, harrowing). Results from a test field at Rusal Aughinish, Ireland, showed an average $\mathrm{pH}$ dropped from $>11$ to $<10.5$ over a period of four months. The average causticity $(\mathrm{NaOH})$ was reduced similarly.

\section{$4 \quad$ Knowledge gaps}

Plant growth on bauxite residues is limited both by geochemical properties, such as alkalinity, salinity/sodicity and metal toxicity, and by physical properties (low permeability, porosity). Recent research on the rehabilitation of bauxite residue storage facilities has shown that the use of in situ remediation (natural rehabilitation) is a viable alternative to soil capping and enables transformation of bauxite residue to a soil capable of supporting a self-sustaining ecosystem. Only limited data are available on long-term behaviour of natural rehabilitation and the soil development that is required to obtain a sustainable vegetation cover. Bauxite residue disposal areas are situated under highly variable climatic conditions. Ongoing laboratory and field tests will be able to generate critical data, which will allow for a full-scale design and closure plan for the bauxite residue disposal areas.

\section{References}

Bray, AW, Stewart, DI, Courtney, R, Rout, SP, Humphreys, PN, Mayes, WM \& Burke, IT 2018, 'Sustained bauxite residue rehabilitation with gypsum and organic matter 16 years after initial treatment', Environmental Science and Technology, vol. 52, pp. 152-161.

Di Carlo, E \& Courtney, R 2018, 'Bioassays for assessing bauxite residue rehabilitation strategies', Fourth Interim Report, Rio Tinto, University of Limerick, World Aluminium.

Jones, BEH \& Haynes, RJ 2011, 'Bauxite processing residue: a critical review of its formation, properties, storage, and revegetation', Critical Reviews in Environmental Science and Technology, vol. 41, pp. 271-315.

McMahon, K 2017, 'Bauxite residue disposal area rehabilitation', Proceedings of 35th International ICSOBA Conference, The International Committee for Study of Bauxite, Alumina \& Aluminium, Quebec.

Power, G, Grafe, M \& Klauber, C 2009, Review of Current Bauxite Residue Management, Disposal and Storage: Practices, Engineering and Science, CSIRO Document DMR-3609, Commonwealth Scientific and Industrial Research Organisation, Canberra.

Santini, T \& Fey, MV 2018, 'From tailings to soil: long-term effects of amendments on progress and trajectory of soil formation and in situ remediation in bauxite residue', Journal of Soil and Sediments, vol. 18, pp. 1935-1949.

Stevenson, FJ 1994, Humus Chemistry: Genesis, Composition, Reactions, 2nd edn, Wiley, New York. 